\title{
SPECIFIC LEARNING DISABILITIES
}

\section{READING DIFFERENCES BETWEEN GREEK DYSLEXIC AND NON-DYSLEXIC UNIVERSITY STUDENTS IN GREECE}

\author{
Sofia Rapti \\ ORCID iD 0000-0002-1614-2818 \\ EdD in Special Education, Special Educator \\ 'Dyslexia Centers - Pavlidis Method' \\ 4th 31 Avgoustou Str., 41221 Larissa, Greece \\ sofrapti@gmail.com
}

\section{George Pavlidis}

$\mathrm{PhD}$ (Psychology), Scientific Director

'Dyslexia Centers - Pavlidis Method'

4th 31 Avgoustou Str., 41221 Larissa, Greece

gpavlidiss@yahoo.com

https://doi.org/10.28925/2518-7635.2019.4.11

\section{ABSTRACT}

Until recently the vast majority of dyslexia research focused on English-speaking and children population, who tend to read significantly slower but mainly inaccurate$l y$, due to the inconsistency of the English language. This led to the wrong assumption that the main feature of dyslexia is inaccurate reading. However, results of research in phonologically consistent languages, such as Greek, Italian, German, Finnish, showed that reading speed is the main deficit of dyslexic readers in either children or adult population. The aim of this research was to investigate the differences in reading performance (reading speed, accuracy and comprehension) between Greek dyslexic university students and age-matched normal controls. A group of 26 Greek dyslexic university students was compared to a group of 28 non-dyslexics matched for age, sex and socio-educational level.

All participants in the dyslexic group had a formal diagnosis of dyslexia. Results showed that dyslexics attained statistically significantly slower reading speed and made more reading errors compared to controls in all testing procedures ( $p<.001)$. However, 
dyslexics read at almost the same speed in both the aloud and silent reading conditions ( $p>.05)$ in contrast to non-dyslexics who read significantly faster in the silent condition ( $p<.05)$. Greek dyslexic university students were accurately differentiated from non-dyslexics based on the reading speed only (accuracy level 98.1\%).

Key-words: dyslexia, adults, University students, reading, reading speed, reading accuracy and comprehension.

(C) Sofia Rapti, George Pavlidis, 2019

\section{INTRODUCTION}

The significance of reading is undoubted today, while learning to read efficiently is a main educational aim. Reading is one of the greatest challenges that students have to encounter daily at university and professional life, especially dyslexics, for whom it is a really hard and demanding process.

Reading is the process of extracting and constructing meaning from a text for a purpose. It is a complex function depending on adequate development of two processes: decoding and comprehension which is the aim of reading.

Decoding involves the identification of written symbols and their translation into pronunciation. Research in the field of specific learning disabilities indicated that reading disabilities are primarily manifested in decoding ability and, hence, dyslexia could be defined as a decoding deficit (Pavlidis, 1990; 2017).

Reading comprehension involves integration of the meanings of written words and sentences in ways that facilitate understanding and perceiving the ideas represented. In brief, comprehension is the purpose of reading.

Decoding and comprehension are two distinctive components of the reading ability. Different parts of the brain are responsible for the different cognitive functions of reading (Geschwind, 1986). Decoding and comprehension are inextricably related. If decoding is inadequate, then purpose of reading is not accomplished. Similarly, there is no successful reading, if the meaning of the word decoded is not adequately perceived. Good decoding skills are the prerequisites for good comprehension.

The aim of the research is to investigate to what extent the reading process is affected by biological-constitutional factors, such as dyslexia.

Dyslexia is the most common among Specific Learning Disabilities affecting $80 \%$ of learning disabled individuals. The incidence of dyslexia in children ranges between 5.3 - 11.8\% (Pavlidis, 1981; 1985; 1986; 1990).

Most dyslexia definitions describe dyslexia as a neurobiological condition that is initially characterised by severe difficulties in learning to read, and later by erratic spelling, major difficulties in transferring thoughts into written form and significant discrepancies between written and oral performance and among cognitive abilities, effort and school performance (Critchley, 1981; Pavlidis \& Giannouli, 2014). Dyslexia is not caused by any known sensory, medical, intelligence, psychoeducational, emotional or environmental factors (Critchley, 1981; Pavlidis, 1990). 
It is well established the hereditary nature and the strong genetic origin of dyslexia (Geschwind, 1986) with 4 boys to 1 girl, worldwide.

Until recently the vast majority of dyslexia research focused on English-speaking and children population (primary school pupils and adolescents). Quite recently, dyslexia began to be researched within higher education, as a result of the steady increase of the number of dyslexic students who enter higher education institutions.

The incidence of dyslexia in higher education varies because of the different criteria used for its definition and evaluation. In the UK, $2 \%$ of students that entered higher education institutions in the academic year 2001-2002 were dyslexics compared to $1.35 \%$ in the academic year 1996-1997. However, almost half of the them had not been diagnosed before entering higher education (Singleton \& Aisbitt, 2001).

In Greek universities, the incidence of dyslexia is estimated at barely $0.16 \%$, (Stampoltzis \& Polychronopoulou, 2008). However, the actual incidence of dyslexia in higher education is difficult to be estimated (Mortimore \& Crozier, 2006), as many dyslexic students decide not to disclose dyslexia upon admission to higher education. It is comforting, though, that the number of dyslexics entering Greek institutions seems to grow over the years following the gradual increase of dyslexic students in higher education reported in other countries.

Among the few dyslexia studies that focused on adult population, much evidence in English concerns adult population in general (not university students necessarily) with childhood diagnoses of dyslexia (Felton et al., 1990; Ransby \& Swanson, 2003, etc.). Few studies until now have compared the reading performance of adult dyslexic university students and normal controls in English (Hatcher et al., 2002; Hanley, 1997; Bruck, 1990), which is a phonologically inconsistent language, even fewer in other languages (Leinonen et al., 2001; Miller-Shaul, 2005; Lehtola \& Lehto, 2000; Laasonen et al., 2012, etc.), while none in Greek, a phonologically consistent language.

Most studies conducted in English focused on deficits in phonological awareness and inaccuracy in phonological decoding even for adults with dyslexia (Felton et al., 1990; Bruck, 1993; Hanley, 1997). Such research findings led to the major assumption that the main feature of dyslexia is inaccurate reading. However, they did not fully investigate the relationship between reading speed and adult dyslexia. On the other hand, in more regular orthographies, studies concentrated on the slow reading speed as the main manifestation of dyslexia without accuracy being necessarily affected (Wimmer, 1993; Landerl et al., 1997; Ziegler et al., 2003). Nevertheless, these studies involved children population, while few studies referred to adult population (Lehtola \& Lehto, 2000; Laasonen et al., 2012). These studies similarly suggested that the regularity of the orthography seems to have an impact on the manifestation of dyslexia in different languages. In regular orthographies, the consistency of grapheme-to-phoneme correspondence enables relatively accurate decoding (Leinonen et al., 2001), but at the expense of reading speed. Lehtola \& Lehto (2000) concluded that the slow reading speed was the most typical characteristic of Finnish dyslexics. Similarly, Laasonen and colleagues (2012) found that $58 \%$ of their dyslexic participants fell into the subgroup "slow but accurate", while the remaining $42 \%$ 
fell into the other two subcategories. Such a distribution indicates that most adult dyslexics are mainly impaired in reading speed and to a smaller extent in reading accuracy, in a shallow orthography at least.

Such findings suggested that different language structures produce different rates of errors and that the more transparent-regular languages produce fewer reading errors from those found in less transparent ones. The slow reading speed is evident, irrespective of language structure, however.

Interestingly though, no studies have ever investigated the reading speed, accuracy and comprehension skills of adult dyslexic (university) students in Greek. Greek language - phonologically consistent and transparent language - has a lot of differences compared to other languages like English - phonologically inconsistent (Pavlidis \& Giannouli, 2003). According to similar findings in other regular orthographies, these differences are likely to affect the reading process and strategies that Greek dyslexics use, because any phonological barriers that could be negatively affecting the reading performance in an inconsistent-irregular language do not exist in a consistent-regular one.

Taking into consideration the former assumptions, the aims of the study are to investigate:

a) the differences in the reading performance (reading speed, accuracy and comprehension) between Greek Dyslexic University students and age-matched normal controls;

b) the symptoms of dyslexia that remain in adult dyslexic students, and

c) how can they be differentiated from non-dyslexics?

We hypothesized that dyslexics will be slower and less accurate in reading while they will attain similar level of comprehension compared to their non-dyslexic peers. Similarly, based on research findings in other phonologically consistenttransparent languages like the Greek, we hypothesized that the reading speed will best differentiate adult dyslexic from non-dyslexic readers.

\section{METHOLOGY}

\section{Design}

The present study was an "experimental" research as the testing conditions were controlled and manipulated by the researcher. The independent variable was the different levels of the grouping variable (dyslexics \& controls) and the set of dependent variables were the categories and subcategories of reading errors, reading speed and comprehension. All the usual-necessary procedures in conducting experimental research were followed (hypotheses, design, validity \& reliability of the instrument, etc.). The experimental design was a "Between Groups" design, because data derived from different groups of participants. The aim was to test the differences between the levels of the grouping variable on each dependent variable. However, as it was of major interest to investigate how each group behaved under the different reading conditions, analyses at a "Repeated Measures" design (same participants exposed in different experimental conditions) were also carried out. 
Finally, logistic regression analyses were carried out to ascertain group membership (dyslexics vs controls) simply on the basis of their performance on the various reading variables (reading speed, types of reading errors, level of reading comprehension).

Participants

A total of 54 Greek University students took part in the research. All participants were either undergraduate or postgraduate students in Greek Universities, most of them studying in the broad urban area of Thessaloniki and Larissa: 38 of them were males and 16 females.

For the needs of the research they were divided into two groups: The first group consisted of twenty-six (26) University students with dyslexia. Eighteen (18) of them were males, while the remaining eight (8) were females. Their age ranged from 17.9 up to 35.1 (mean age 22.1 years old). The second group consisted of twenty-eight (28) non-dyslexic University students. Twenty (20) of them were males and eight (8) females. Their age ranged from 18.2 up to 35.3 years old (mean age 22.0 years old). The two groups were roughly matched for age, sex and socio-educational background.

Sampling method and selection criteria

All dyslexic participants were selected based on the "Quota" sampling method, in order to satisfy certain inclusion criteria. It was required for all dyslexic participants to have a formal diagnosis of dyslexia from a recognised public or private diagnostic center. Potential dyslexic students without a formal diagnosis were excluded from the research.

The majority of dyslexic students were retrieved from 'Dyslexia Centers - Pavlidis Method' that function under the scientific direction and management of Prof. G. Th. Pavlidis. The rest of them were selected from Greek Universities of the broad urban area of Thessaloniki and Larissa.

After the selection of the dyslexic group, 28 non-dyslexic students matched for age, sex and socio-educational level were selected as the control group.

Both groups consisted of individuals of similar IQ, socio-economic background and educational history. They were also matched based on ethnicity, nationality and mother tongue (Greek), while within each group they also had the same experience, so as to establish that the groups were different between them only in the task under study (Pavlidis, 1990).

Inclusion criteria

Both groups had to fulfill the following inclusion criteria, as to be included in the research (Pavlidis, 1990):

- Normal IQ (average or above average);

- Normal or corrected vision or hearing;

- Greek being their native language;

- Average or above average socio-economic background (individuals from the lowest socio-economic status were excluded from the study);

- Adequate educational opportunities;

- Not on any psychoactive medication known to affect cognitive processes or within its washout period; 
- No overt emotional problems, prior to entering school;

- No neurological handicaps that could account for reading problems (e.g. brain injury brain tumor, etc.).

Regarding the non-dyslexic student group, their IQ wasn't tested, because as it consisted of highly educated population, they were expected to have at least normal intelligence.

All legal and ethical procedures were faithfully followed during the conduct of the study.

All students were informed in writing about the aim of the research and were asked for their permission to participate in the study. Those willing to participate constituted the two groups.

\section{Experimental procedure}

The experimental procedure took place in accessible and suitable settings that provided comfortable, private and safe place for both the participant and the researcher.

The reading performance of adult dyslexic and non-dyslexic students was evaluated in 3 different reading materials. Participants read both aloud and silently, while being timed and tape-recorded for further analysis. After reading each piece of text, they answered the appropriate comprehension questions.

Reading materials were presented in a counterbalanced fashion, in order to neutralize the possible order effect.

The duration of the experimental procedure was approximately 25 minutes for each participant.

\section{Tests and materials}

- The materials used were the following:

- 3 Reading tests: 2 reading texts of varying difficulty and a list of words of raising difficulty.

- $\quad$ Reading comprehension questions: 5 reading comprehension questions for each text.

- Tape-recorder for further analysis of the reading errors.

- Chronometer for the evaluation of participants' reading speed.

- $\quad$ Reading performance scoring sheet to record reading data.

\section{Scoring}

The reading errors of both groups were categorised and analysed based on "The Reading Errors Analysis Instrument" developed by Prof. G. Th. Pavlidis. This tool includes 13 main categories of reading errors with several subcategories:

\section{Categories and Subcategories of reading errors:}

1. Hems: Participant hesitates or "drags" a letter when reading.

e.g. In the way to the ...heeem... school

2. Repetitions: Participant repeats a letter, syllable or word while reading.

ENGLISH e.g. $\boldsymbol{t}$ - today / GREEK e.g. $\boldsymbol{\gamma}$ - $\boldsymbol{\gamma} \rho \eta \dot{\gamma}$ oo os /grigoros/ (= fast)

3. Syllabication: Participant separates the syllables of the word during reading.

e.g. $\tau \dot{\omega} \_\rho a /$ to ra/ (= now) - participant clearly "cuts" the syllables $\tau \omega /$ to/ and $\rho \alpha$ $/ \mathrm{ra} /$ of the word $\tau \dot{\omega} \rho$ a /tora/ 
4. Substitutions: Participant substitutes a letter, syllable or word by another while reading.

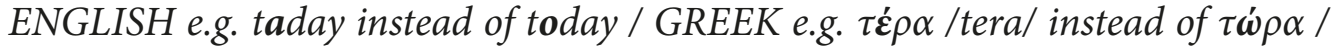
tora/ (= now)

5. Reversals: Participant reverses letters, syllables or words in reading.

ENGLISH e.g. saw instead of was / GREEK e.g. $\boldsymbol{\alpha} \boldsymbol{v} /$ an/ instead of $\boldsymbol{v \alpha} / \mathrm{na} /$

6. Omissions: Participant omits letters, syllables or words while reading.

ENGLISH e.g. cild instead of child / GREEK e.g. $\tau \rho \alpha /$ tra/ instead of $\tau \boldsymbol{\omega} \rho \alpha$ /tora/ (=now)

7. Additions: Participant adds letters, syllables or words when reading.

ENGLISH e.g. todray instead of today / GREEK e.g. $\tau \omega \dot{\tau} \rho \alpha$ /totra/ instead of $\tau \omega \dot{\omega} \alpha$ /tora/ (= now)

8. Misintonation: Participant incorrectly locates the intonation mark of a word in reading.

e.g. $\tau \omega \rho \dot{\alpha} /$ torà/ instead of $\tau \dot{\boldsymbol{\omega}} \rho \alpha /$ tòra/

9. Endings: Participant substitutes the ending of a word with another existing ending and read another similar word.

ENGLISH e.g. playing instead of plays / GREEK e.g. $\pi \dot{\eta} \gamma \boldsymbol{\alpha} / p i g a /$ (= I went) instead of $\pi \dot{\gamma} \gamma \varepsilon$ /pige/ (= he went)

10. Punctuation: Participant substitutes, omits or adds a punctuation mark during reading.

e.g. the participant reads the sentence as having a full stop instead of a question mark or vice versa

11. Point Marks: Participant does not take into account point marks (apostrophe, disjunction, etc.) while reading.

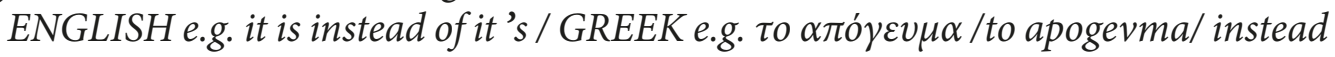
of $\tau^{\prime} \alpha \pi$ ó $\mathcal{} \varepsilon u \alpha /$ t'apogevma/ (= the afternoon)

12. Line Missing: Participant misses a whole line while reading.

13. Repetitions of Errors: Participant repeats any of the errors of the previous categories.

\section{RESULTS}

\section{Between groups analysis}

The quantitative differences between the two groups in terms of the reading parameters (speed, accuracy and comprehension) are presented in the following tables (Table 1 and 3).

Table 1

Reading Speed and Comprehension means Comparison between dyslexic and non-dyslexic students

\begin{tabular}{|l|c|c|c|c|c|c|c|}
\hline & \multicolumn{3}{|c|}{ Dyslexic Students } & \multicolumn{3}{c|}{ Controls } & \\
\hline Variables & Mean & SD & Min-Max & Mean & SD & Min-Max & p-value \\
\hline Easy Text & & & & & & & \\
\hline
\end{tabular}




\begin{tabular}{|l|c|c|c|c|c|c|c|}
\hline Reading Speed Aloud & $\mathbf{1 1 3}$ & 25.35 & $49-150$ & $\mathbf{1 6 5}$ & 21.47 & $123-200$ & $\mathbf{. 0 0 0}$ \\
\hline Reading Speed Silent & $\mathbf{1 0 7}$ & 27.11 & $56-154$ & $\mathbf{1 9 3}$ & 47.02 & $120-278$ & $\mathbf{. 0 0 0}$ \\
\hline Reading Comprehension Silent & $\mathbf{1 7 \%}$ & 21.31 & $0 \%-70 \%$ & $\mathbf{4 0 \%}$ & 28.09 & $0 \%-100 \%$ & $\mathbf{. 0 0 0}$ \\
\hline Difficult Text & & & & & & & \\
\hline Reading Speed Aloud & $\mathbf{1 1 5}$ & 23.00 & $54-153$ & $\mathbf{1 7 3}$ & 22.35 & $138-224$ & $\mathbf{. 0 0 0}$ \\
\hline Reading Speed Silent & $\mathbf{1 1 6}$ & 28.54 & $41-164$ & $\mathbf{2 0 5}$ & 49.94 & $140-320$ & $\mathbf{. 0 0 0}$ \\
\hline Reading Comprehension Silent & $\mathbf{1 5 \%}$ & 25.02 & $0 \%-100 \%$ & $\mathbf{3 4 \%}$ & 26.28 & $0 \%-100 \%$ & $\mathbf{. 0 0 1}$ \\
\hline Word List & & & & & & & \\
\hline Reading Speed Total & $\mathbf{4 5}$ & 11.04 & $25-66$ & $\mathbf{7 2}$ & 11.69 & $54-96$ & $\mathbf{. 0 0 0}$ \\
\hline Reading Speed 1' & $\mathbf{6 6}$ & 10.19 & $50-84$ & $\mathbf{8 6}$ & 10.74 & $66-109$ & $\mathbf{. 0 0 0}$ \\
\hline Reading Speed beyond 1' till the end & $\mathbf{3 6}$ & 9.22 & $20-57$ & $\mathbf{5 8}$ & 9.26 & $41-73$ & $\mathbf{. 0 0 0}$ \\
\hline
\end{tabular}

Adult dyslexic students were statistically significantly slower in all reading conditions $(\mathrm{p}<.001)$ and they attained statistically significantly lower level of comprehension in the silent condition $(\mathrm{p}<.001$ and $\mathrm{p}<.05)$ in all reading conditions (see Table 1). It is remarkable though that in the aloud reading condition, both groups attained similar levels of comprehension.

Based on normality tests (Kolmogorof-Smirnof), both groups had a normal distribution on all reading speed variables $(\mathrm{p}>.05)$, while normality was violated on reading comprehension $(\mathrm{p}<.05)$. Consequently, the parametric Independentsamples t-test and the non-parametric Mann-Whitney test have respectively been used for the analysis.

Results showed that the variables that revealed a significant mean difference between adult dyslexic students and controls in all experimental conditions $(p<.001)$, having a strong effect to the population at the same time, were reading speed in all tasks [easy text aloud: $t(52)=-8.15, \mathrm{p}<.001, \mathrm{r}=.75 /$ easy text silent: $t(44)=-8.34$, $\mathrm{p}<.001, \mathrm{r}=.78$ / difficult text aloud: $t(52)=-9.41, \mathrm{p}<.001, \mathrm{r}=.79 /$ difficult text silent: $t(44)=-8.08, \mathrm{p}<.001, \mathrm{r}=.79 /$ word list total: $t(52)=-8.52, \mathrm{p}<.001, \mathrm{r}=.76 /$ word list $1^{\prime}: t(52)=-7.05, \mathrm{p}<.001, \mathrm{r}=.70 /$ word list beyond $\left.1^{\prime}: t(52)=-8.69, \mathrm{p}<.001, \mathrm{r}=.77\right]$ and reading comprehension in the silent reading condition (easy text: $\mathrm{U}=172.000$, $\mathrm{z}=-3.406, \mathrm{p}<.001, \mathrm{r}=-.46)$. These variables are presented in Table 2 below:

Table 2

Variables highly differentiating the 2 groups: Significance \& effect size

\begin{tabular}{|l|c|c|c|c|c|c|}
\hline \multirow{2}{*}{ Reading Variables } & \multicolumn{2}{|c|}{ Easy Text } & \multicolumn{2}{c|}{ Difficult Text } & \multicolumn{2}{c|}{ Word List } \\
\cline { 2 - 7 } & $\mathbf{P}$ & $\mathbf{r}$ & $\mathbf{p}$ & $\mathbf{r}$ & $\mathbf{p}$ & $\mathbf{r}$ \\
\hline Reading Speed Aloud (Total) & $<.001$ & .75 & $<.001$ & .79 & $<.001$ & .76 \\
\hline Reading Speed Silent & $<.001$ & .78 & $<.001$ & .79 & & \\
\hline Reading Comprehension Silent & $<.001$ & .46 & $=.001$ & .41 & & \\
\hline Reading Speed 1' & & & & & $<.001$ & .70 \\
\hline Reading Speed beyond 1' & & & & & $<.001$ & .77 \\
\hline
\end{tabular}

The reading error differences between the two groups are presented per reading material in the following table: 


\section{Reading Error means:}

\section{Comparison between dyslexics \& controls in the easy text}

\begin{tabular}{|c|c|c|c|c|c|c|c|}
\hline \multirow{2}{*}{ Easy Text } & \multicolumn{6}{|c|}{ GROUP } & \multirow[b]{3}{*}{ p-value } \\
\hline & \multicolumn{3}{|c|}{ Dyslexic Students } & \multicolumn{3}{|c|}{ Normal Controls } & \\
\hline Variables & Mean & SD & Median & Mean & SD & Median & \\
\hline Hems & 9.28 & 8.69 & 6.00 & 1.00 & 1.37 & 0.50 & .000 \\
\hline Repetitions & 9.12 & 9.48 & 6.38 & 2.76 & 3.07 & 1.67 & .000 \\
\hline Syllabication & 1.58 & 3.09 & 0.00 & 0.04 & 0.19 & 0.00 & .000 \\
\hline Substitutions & 2.29 & 1.71 & 1.67 & 0.39 & 0.76 & 0.00 & .000 \\
\hline Misintonation & 0.52 & 0.79 & 0.00 & 0.08 & 0.31 & 0.00 & .006 \\
\hline Endings & 1.30 & 1.79 & 0.50 & 0.04 & 0.19 & 0.00 & .000 \\
\hline Total Errors ${ }^{*}$ & 27.12 & 21.53 & 21.62 & 6.16 & 5.27 & 5.00 & .000 \\
\hline Timing Errors $^{* *}$ & 20.35 & 19.68 & 14.26 & 3.79 & 4.12 & 2.35 & .000 \\
\hline Accuracy Errors & 6.79 & 4.02 & 6.00 & 2.36 & 1.77 & 2.52 & .000 \\
\hline
\end{tabular}

* Total errors: the sum of all reading errors

** Timing errors: the sum of reading error categories that reduce the speed of reading (e.g. hems, repetitions, syllabications)

*** Accuracy errors: the sum of reading error categories that affect the accuracy of reading (e.g. Substitutions, Omissions, Additions, etc.)

Table 3(b)

\section{Reading Error means:}

\section{Comparison between dyslexics \& controls in the difficult text}

\begin{tabular}{|c|c|c|c|c|c|c|c|}
\hline \multirow[t]{2}{*}{ Difficult Text } & \multicolumn{6}{|c|}{ GROUP } & \multirow[b]{3}{*}{ p-value } \\
\hline & \multicolumn{3}{|c|}{ Dyslexic Students } & \multicolumn{3}{|c|}{ Normal Controls } & \\
\hline Variables & Mean & SD & Median & Mean & SD & Median & \\
\hline Hems & 9.66 & 7.88 & 6.25 & 1.28 & 1.33 & 0.82 & .000 \\
\hline Repetitions & 11.22 & 8.21 & 10.17 & 2.17 & 3.18 & 0.89 & .000 \\
\hline Syllabication & 1.24 & 1.69 & 0.75 & 0.03 & 0.14 & 0.00 & .000 \\
\hline Substitutions & 2.64 & 1.67 & 2.68 & 0.57 & 0.82 & 0.00 & .000 \\
\hline Omissions & 1.01 & 1.01 & 0.89 & 0.34 & 0.54 & 0.00 & .003 \\
\hline Misintonation & 1.06 & 0.67 & 0.89 & 0.22 & 0.35 & 0.00 & .000 \\
\hline Endings & 1.82 & 1.58 & 1.50 & 0.75 & 0.74 & 0.75 & .001 \\
\hline Total Errors & 31.41 & 19.25 & 23.68 & 6.99 & 5.34 & 6.13 & .000 \\
\hline Timing Errors & 22.66 & 16.28 & 17.13 & 3.53 & 4.06 & 2.40 & .000 \\
\hline Accuracy Errors & 8.67 & 4.55 & 8.59 & 3.49 & 1.97 & 3.56 & .000 \\
\hline
\end{tabular}

Table 3(c)

Reading Error means:

Comparison between dyslexics \& controls in the word list

\begin{tabular}{|c|c|c|c|c|c|c|c|}
\hline Word List & & & & & & & \\
\hline & & xic Stt & & . & al Cc & & \\
\hline Variables & Mean & SD & Median & Mean & SD & Median & p-value \\
\hline Hems & 17.14 & 16.55 & 13.00 & 2.18 & 2.45 & 1.33 & .000 \\
\hline
\end{tabular}




\begin{tabular}{|l|c|c|c|c|c|c|c|}
\hline Repetitions & 21.62 & 22.29 & 15.00 & 4.29 & 4.91 & 2.00 & $\mathbf{. 0 0 0}$ \\
\hline Syllabication & 9.49 & 10.23 & 6.67 & 0.55 & 0.93 & 0.00 & $\mathbf{. 0 0 0}$ \\
\hline Substitutions & 4.85 & 2.67 & 4.67 & 1.79 & 1.88 & 1.33 & $\mathbf{. 0 0 0}$ \\
\hline Omissions & 2.18 & 2.23 & 1.33 & 0.60 & 0.78 & 0.33 & $\mathbf{. 0 0 0}$ \\
\hline Misintonation & 2.39 & 2.94 & 1.66 & 0.24 & 0.55 & 0.00 & $\mathbf{. 0 0 0}$ \\
\hline Endings & 2.21 & 1.78 & 2.00 & 0.33 & 0.53 & 0.00 & $\mathbf{. 0 0 0}$ \\
\hline Total Errors & 62.18 & 52.74 & 50.33 & 10.36 & 9.47 & 7.00 & $\mathbf{. 0 0 0}$ \\
\hline Timing Errors & 48.88 & 45.55 & 39.66 & 7.01 & 7.05 & 4.66 & $\mathbf{. 0 0 0}$ \\
\hline Accuracy Errors & 12.39 & 8.34 & 10.67 & 3.22 & 3.04 & 2.66 & $\mathbf{. 0 0 0}$ \\
\hline
\end{tabular}

Adult dyslexic students made significantly more reading errors of almost all categories compared to their non-dyslexic peers $(\mathrm{p}<.001$ and $\mathrm{p}<.05)$ in all reading tasks (see Table 3).

Normality tests revealed that the scores of both groups on most reading errors variables were not normally distributed $(\mathrm{p}<.05)$. This statistical constraint enforced the use of the non-parametric Mann-Whitney test for most analyses.

Results showed that in all reading materials the total sum of reading errors as well as the sum of timing (Hems, Repetitions etc.) and accuracy errors (Substitutions, Omissions, etc.) revealed a highly significant mean difference between groups ( $\mathrm{p}<.001)$ having a strong effect to the population at the same time: [a) easy text: Total Errors: $U$ $=64.000, \mathrm{z}=-5.187, \mathrm{p}<.001, \mathrm{r}=-.71 /$ Timing Errors: $U=71.500, \mathrm{z}=-5.073, \mathrm{p}<.001, \mathrm{r}$ $=-.69$ / Accuracy Errors: $t(34)=5.17, \mathrm{p}<.001, \mathrm{r}=-.66, \mathrm{~b})$ difficult text: Total Errors: $U$ $=48.000, \mathrm{z}=-5.472, \mathrm{p}<.001, \mathrm{r}=-.74 /$ Timing Errors: $U=53.500, \mathrm{z}=-5.382, \mathrm{p}<.001$, $\mathrm{r}=-.73$ / Accuracy Errors: $t(34)=5.35, \mathrm{p}<.001, \mathrm{r}=.68, \mathrm{c})$ word list: Total Errors: $U=$ 44.000, $\mathrm{z}=-5.541, \mathrm{p}<.001, \mathrm{r}=-.75 /$ Timing Errors: $U=40.000, \mathrm{z}=-5.611, \mathrm{p}<.001, \mathrm{r}$ $=-.76 /$ Accuracy Errors: $U=78.500, \mathrm{z}=-4.951, \mathrm{p}<.001, \mathrm{r}=-.67]$.

These categories along with the subcategories of reading errors that highly differed between the two groups are shown in the following table (table 4). It is noteworthy that the majority of reading error categories highly differentiating between dyslexics and controls were timing errors (hems, repetitions and syllabications), which are related to the speed of reading.

Table 4

\section{Reading errors variables highly differentiating the 2 groups: Significance \& effect size}

\begin{tabular}{|l|c|c|c|c|c|c|}
\hline \multirow{2}{*}{ Reading Errors } & \multicolumn{2}{|c|}{ Easy Text } & \multicolumn{2}{c|}{ Difficult Text } & \multicolumn{2}{c|}{ Word List } \\
\cline { 2 - 7 } & $\mathbf{p}$ & $\mathbf{r}$ & $\mathbf{p}$ & $\mathbf{~}$ & $\mathbf{p}$ & $\mathbf{R}$ \\
\hline Hems & $<.001$ & -.81 & $<.001$ & -.80 & $<.001$ & -.71 \\
\hline Repetitions & $<.001$ & -.46 & $<.001$ & -.67 & $<.001$ & -.67 \\
\hline Syllabication & $<.001$ & -.44 & $<.001$ & -.56 & $<.001$ & -.80 \\
\hline Substitutions & $<.001$ & -.64 & $<.001$ & -.67 & $<.001$ & -.59 \\
\hline Total Errors & $<.001$ & -.71 & $<.001$ & -.74 & $<.001$ & -.75 \\
\hline Timing Errors & $<.001$ & -.69 & $<.001$ & -.73 & $<.001$ & -.76 \\
\hline Accuracy Errors & $<.001$ & -.66 & $<.001$ & -.68 & $<.001$ & -.67 \\
\hline
\end{tabular}




\section{Within groups analysis}

Comparisons and analyses have also been made within each group:

1. between aloud and silent reading conditions, and

2. among the different reading materials.

a) Based on the sampling distribution, the Paired-samples t-test or its nonparametric equivalent Wilcoxon signed-rank test were used for the comparisons within each group between aloud and silent reading (2 experimental conditions).

b) Based on normality tests, the repeated-measures ANOVA or its nonparametric Friedman's ANOVA were used for the comparison within each group among the different reading materials (3 experimental conditions).

a) Between aloud and silent reading: Results showed a totally opposite pattern between dyslexics' and controls' performance in the aloud and silent reading condition. In contrast to non-dyslexics who read significantly faster silently [easy text: $t(27)=-3.436, \mathrm{p}<.05, \mathrm{r}=.55$ / difficult text: $t(27)=-3.744$, $\mathrm{p}<.001, \mathrm{r}=.58]$, dyslexics read at almost the same rate in both aloud and silent reading condition, as shown by the non-significant differences found (see figure 1 below). Similarly, the controls attained higher level of comprehension in the silent condition, as opposed to dyslexics, who showed a trend to comprehend better in aloud reading, although the differences were not found to be significant for neither of the two groups ( $p>.05)$.

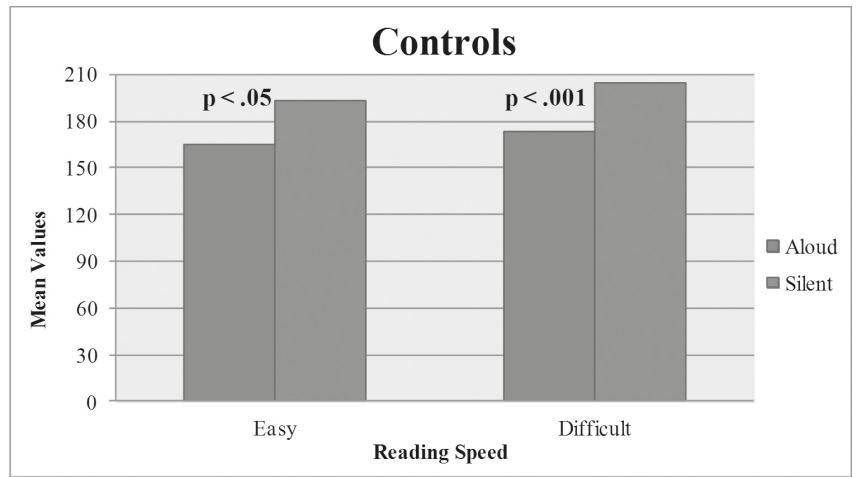

Figure 1. Dyslexics' \& controls' reading speed differences between aloud \& silent reading conditions

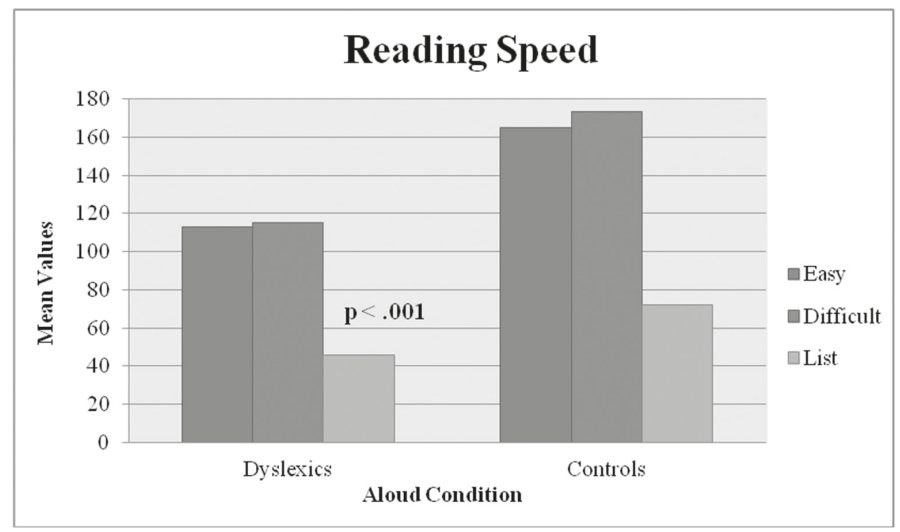

Figure 2. Dyslexics' \& controls' reading speed differences among reading materials 
c) Among reading materials: As expected, either dyslexics' or controls' reading speed was significantly affected by the reading material they were reading [dyslexics: $\mathrm{F}(2,50)=313.75, \mathrm{p}<.001, \omega^{2}=.71 /$ controls: $\mathrm{F}(2,54)=$ $510.31, \mathrm{p}<.001, \omega^{2}=.85$ ] with the list of words being the most difficult in terms of reading speed for both groups (see figure 2 below).

Similarly, dyslexics' reading accuracy was significantly affected by the reading material, $\chi^{2}(2)=27.00, p<.001$. Although they made comparable reading errors in the easy and difficult text ( $p>.05)$, they made significantly more reading errors in the list of words compared to either the easy, $T=11.00, \mathrm{z}=-4.178, \mathrm{p}<.001, \mathrm{r}=$ -.58 , or the difficult text, $T=16.00, \mathrm{z}=-4.051, \mathrm{p}<.001, \mathrm{r}=-.56$. On the contrary, the total reading errors made by non-dyslexics did not significantly increase in quantity over the course of the 3 reading materials, $\chi^{2}(2)=4.96, p>.05$ (see figure 3, appendix).

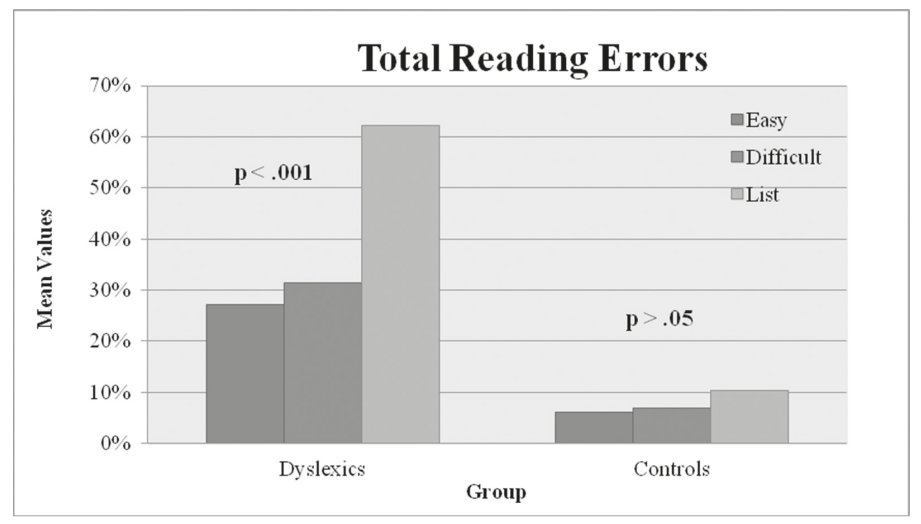

Figure 3. Dyslexics' \& controls' reading errors differences among reading materials

\section{LOGISTIC REGRESSION ANALYSIS}

Logistic Regression Analysis was used, in order to investigate whether it was possible to predict-classify which group a participant was likely to belong to, based on certain predictor variables. Reading errors, speed and comprehension were the predictor variables of the group membership. The method used was the forward stepwise (Likelihood ratio, LR). The analysis was conducted per reading material.

In the easy reading text, the silent reading speed was the predictor entered at step 1 , because it had the highest value in the test statistic $(\mathrm{p}<.001)$. The aloud reading speed was the second predictor entered at step 2, as it had the next highest score $(\mathrm{p}<.001)$. A test of the full model at both steps against a constant only model was statistically significant, indicating that predictors reliably distinguished between dyslexics and controls (Step 1: $\chi^{2}=52.92, \mathrm{p}<.001$. Step $\left.2: \chi^{2}=66.80, \mathrm{p}<.001\right) . \mathrm{R}^{2}$ at both steps indicated a strong relationship between prediction and grouping. The following table indicates how well the model predicts group membership. 
Classification table indicating group membership in the easy text

\begin{tabular}{|c|c|c|c|c|c|}
\hline \multicolumn{2}{|c|}{ Observed } & \multicolumn{3}{c|}{ Predicted } \\
\cline { 4 - 6 } \multicolumn{2}{|c|}{} & \multicolumn{2}{c|}{ GROUP } & \multirow{2}{*}{ Percentage Correct } \\
\cline { 3 - 6 } Step 1 & \multirow{3}{*}{ GROUP } & Dyslexics & 24 & 2 & 92.3 \\
\cline { 3 - 6 } & & Controls & 2 & 26 & 92.9 \\
\cline { 3 - 6 } & \multirow{2}{*}{ Overall Percentage } & & 1 & 92.6 \\
\hline \multirow{3}{*}{ Step 2 } & \multirow{2}{*}{ GROUP } & Dyslexics & 25 & 27 & 96.2 \\
\cline { 3 - 6 } & & Controls & 1 & & 96.4 \\
\cline { 2 - 6 } & \multicolumn{2}{|c|}{ Overall Percentage } & & 96.3 \\
\hline
\end{tabular}

The model significantly predicts group membership based on only 2 variables, aloud and silent reading speed, correctly classifying 25 out of 26 dyslexics and 27 out of 28 non-dyslexics. The total accuracy of classification at step 2 was $96.3 \%$.

In the difficult reading material, the aloud reading speed was entered at step 1 , as it had the highest score statistic $(\mathrm{p}<.001)$. The silent reading speed was entered at step 2. A test of the full model at both steps against a constant only model was statistically significant, indicating that predictors reliably discriminated between dyslexics and non-dyslexics (Step 1: $\chi^{2}=57.71, \mathrm{p}<.001$. Step 2: $\chi^{2}=66.54, \mathrm{p}<.001$ ). $\mathrm{R}^{2}$ at both steps indicated a strong relationship between prediction and grouping (see the classification table below).

Table 6

Classification table indicating group membership in the difficult text

\begin{tabular}{|c|c|c|c|c|c|}
\hline \multicolumn{2}{|c|}{ Observed } & \multicolumn{3}{c|}{ Predicted } \\
\cline { 3 - 6 } \multicolumn{2}{|c|}{} & \multicolumn{2}{|c|}{ GROUP } & \multirow{2}{*}{ Percentage Correct } \\
\cline { 3 - 6 } Step 1 & \multirow{2}{*}{ GROUP } & Dyslexics & 25 & 1 & 96.2 \\
\cline { 3 - 6 } & & Controls & 3 & 25 & 89.3 \\
\cline { 3 - 6 } & \multirow{3}{*}{ Overall Percentage } & & & 92.6 \\
\hline \multirow{2}{*}{ Step 2 } & \multirow{2}{*}{ GROUP } & Dyslexics & 26 & 0 & 100.0 \\
\cline { 2 - 6 } & & Controls & 1 & 27 & 96.4 \\
\cline { 2 - 6 } & \multicolumn{2}{|c|}{ Overall Percentage } & & & $\mathbf{9 8 . 1}$ \\
\hline
\end{tabular}

This model significantly predicts group membership based on the same 2 variables, aloud and silent reading speed, correctly classifying all dyslexics while misclassifying only one of the participants of the control group. The total accuracy of classification at step 2 reached $98.1 \%$.

In the list of words, the aloud reading speed was the predictor entered at step, as it had the highest value in the test statistic $(\mathrm{p}<.001)$. Syllabication errors were the second predictor entered at step $2(\mathrm{p}<.001)$. A test of the full model at both steps against a constant only model was statistically significant, indicating that the predictors reliably distinguished between dyslexics and controls (Step 1: $\chi^{2}=$ 45.69, $\mathrm{p}<.001$. Step 2: $\left.\chi^{2}=52.01, \mathrm{p}<.001\right)$. $\mathrm{R}^{2}$ at both steps indicated a moderately strong relationship between prediction and grouping (see table 7 ). 
Classification table indicating group membership in the word list

\begin{tabular}{|c|c|c|c|c|c|}
\hline & \multirow{3}{*}{\multicolumn{2}{|c|}{ Observed }} & \multicolumn{3}{|c|}{ Predicted } \\
\hline & & & \multicolumn{2}{|c|}{ GROUP } & \multirow{2}{*}{ Percentage Correct } \\
\hline & & & Dyslexics & Controls & \\
\hline \multirow{3}{*}{ Step 1} & \multirow{2}{*}{ GROUP } & Dyslexics & 22 & 4 & 84.6 \\
\hline & & Controls & 4 & 24 & 85.7 \\
\hline & \multicolumn{2}{|c|}{ Overall Percentage } & & & 85.2 \\
\hline \multirow{3}{*}{ Step 2} & \multirow{2}{*}{ GROUP } & Dyslexics & 22 & 4 & 84.6 \\
\hline & & Controls & 1 & 27 & 96.4 \\
\hline & \multicolumn{2}{|c|}{ Overall Percentage } & & & 90.7 \\
\hline
\end{tabular}

This model can significantly predict group membership based on reading speed and syllabication errors with a classification accuracy of $90.7 \%$. Similarly, to the previous conditions, reading speed was actually found to be the best predictor in the word list, as syllabication errors belong to timing errors, which reduce the speed without affecting the accuracy of reading.

Summing up, the main finding that came out from the Logistic Regression was that the speed of reading in context was the most powerful predictor, in order to discriminate between the two groups and could be suggested as an almost infallible criterion for "diagnosing" dyslexia in adults.

\section{DISCUSSION}

As expected adult dyslexic University students were statistically significantly slower in reading compared to controls in all 3 reading materials (easy text, difficult text, word list) and irrespectively of the reading condition (aloud or silent). Such a result was not surprising, as the slow reading speed is one of the main manifestations of developmental dyslexia (Pavlidis, 2019; Ziegler et al., 2003; Shaywitz, 1998). These findings are in line with the relevant literature, which confirms the speed deficit of adult dyslexics (Hatcher et al., 2002; Lehtola \& Lehto, 2000; Bruck, 1990; Meyler \& Breznitz, 2003).

Regarding reading comprehension, there were no significant differences between dyslexics and controls in any of the texts in the aloud condition, while significant differences were found between groups in the silent condition. Such findings agree with the current literature, which suggests that dyslexics may or may not encounter comprehension difficulties, and if such difficulties are present, they may result from the dyslexics' decoding deficit (Lyon, Shaywitz, \& Shaywitz, 2003). Besides, if dyslexics had a comprehension deficit, it should be evident in both aloud and silent reading. Thus, the mode of reading, aloud or silent, has a different impact on reading comprehension depending on the reader's proficiency, as it is discussed below.

Also, as predicted, adult dyslexic students were significantly less accurate than non-dyslexics in all reading materials administered to them. They made significantly more reading errors in almost every reading category compared to controls. 
Inaccurate reading is among the most crucial features of dyslexia, even in adulthood (Critchley, 1981). Significant differences in the accuracy level between dyslexics and controls are also reported by the current literature (Felton et al., 1992; Hatcher et al., 2002; Leinonen et al., 2001). However, most of the errors made by dyslexics were timing errors, errors that reduce the speed of reading, indicating that the slow reading speed is the main hurdle of dyslexic readers.

The speed deficit of dyslexics was further supported by the significant negative correlations found between timing errors and reading speed, suggesting that as the timing errors increase the speed of reading decreases, while for the control group less significant correlations were found between timing errors and speed.

Table 8

Correlations among reading components (Spearman's correlation coefficients)

\begin{tabular}{|c|c|c|}
\hline & Dyslexics' Reading Speed & Controls' Reading Speed \\
\hline Easy Timing Errors & $-.668^{* *}$ & -.185 \\
\hline Difficult Timing Errors & $-.676^{* *}$ & $-.467^{*}$ \\
\hline List Timing Errors & $-.708^{* *}$ & $-.432^{*}$ \\
\hline
\end{tabular}

$$
{ }^{* *} \mathrm{p}<.01,{ }^{*} \mathrm{p}<.05
$$

Finally, the essence of the logistic regression analysis was that the reading variables - reading speed, accuracy and comprehension - could accurately discriminate Greek dyslexic from non-dyslexic University students. The analyses conducted revealed that the reading speed in context could best differentiate between dyslexics and controls with an accuracy of classification reaching $98.1 \%$, correctly classifying $100 \%$ of dyslexics, but misclassifying only one non-dyslexic. One of the explanations is that it is possible in the control (normal readers) group to have included untested dyslexics. This finding confirms Shaywitz \& Shaywitz (2005) who argued that reading speed could be the most useful clinical criterion to distinguish disabled from non-disabled readers in adulthood (Pavlidis, 2018; Rapti, Pavlidis \& Garner, 2018; 2013).

Although non-dyslexics read significantly faster in the silent condition, in line with Taylor and Connor (1982) who reported that proficient readers read faster silently, dyslexics read at the same rate in both aloud and silent condition. This finding amplifies the speed deficit of dyslexics, who, even when reading silently, a process that do not require so much effort in order to decode, they are still struggling to read, with their speed being stuck at very low levels. Comparing the speed of both groups in context and out of context, it is concluded that both groups were significantly slower in the list of single words, indicating that both dyslexics and controls were affected by the lack of context and the structure of the word list. This comes in agreement with research evidence which points out that familiar words are read faster than unfamiliar (DeFior et al., 2002; Leinonen et al., 2001; Wimmer \& Goswami, 1994), and other research findings displaying that poor readers rely heavily on context for word recognition (Bruck, 1990; Ben-Dror 
et al., 1990; Shaywitz \& Shaywitz, 2005). The non-dyslexics were similarly affected by the presence or lack of context, as reflected in their reading speed.

No significant differences were found in the level of reading comprehension between aloud and silent reading condition for either group. However, it is remarkable that an opposite pattern was shown. While non-dyslexics comprehended better silently, dyslexics tended to comprehend better aloud. This trend is in accordance with research evidence suggesting that proficient readers can go directly to meaning, whereas poor readers rely on aloud reading to extract meaning (Taylor \& Connor, 1982; Miller \& Smith, 1989). This explains why significant differences between dyslexics and controls were found only in the silent condition. It is noteworthy that in silent reading the reading comprehension of non-dyslexics increases, while it decreases in the dyslexics.

Finally, as expected, dyslexics were significantly less accurate in reading out of context, in contrast to non-dyslexics who made comparable reading errors in both reading in context and out of context. The error rate differences of dyslexics between text and list of single-unrelated reading can be attributed to the lack of context and the structure of the word list. However, the reading accuracy of non-dyslexics is not affected by the lack of context in contrast to reading speed, as mentioned before. Support for these findings come from the research of Bruck (1990) and Lehtola and Lehto (2001).

The results illuminate the importance of daily extensive reading practice for a better reading speed, which is essential not only for normal-achieving population but for dyslexic readers as well, as reading speed was found to be the main deficit for dyslexics and the main differentiating factor between dyslexics and controls with a very high accuracy $(98.1 \%)$.

Also, results might be helpful for the accurate diagnosis of adult dyslexics based on reading speed, as it seems that the slow reading speed is a lifelong condition for dyslexics and the most reliable diagnostic criterion, irrespective of age, culture, race or language (Pavlidis, 2018; Pavlidis \& Goula, 2004). Such findings are also in accordance with similar research findings in other phonologically consistent languages, such as Finnish and German.

\section{CONCLUSIONS}

In conclusion, results might be helpful for the effective treatment of the difficulties that encounter dyslexic university students, due to their constitutional reading deficit. Any treatment methods and programmes used for dyslexics must be considerably focused on the enhancement of their reading speed, especially when it comes to university students for whom reading speed is a highly essential skill.

Hopefully, this study will raise awareness of dyslexia within higher education and will highlight the importance of reading speed measurements in a diagnostic battery for all ages of dyslexics, internationally (Pavlidis, 1981; 1990; 2017). This research will be useful for both psychologists and school educators as it highlights the need for differential assessment-diagnosis and teaching internationally. 


\section{REFERENCES}

Ben-Dron, I., Pollatsek, A., \& Scarpati, S. (1991). Word Identification in Isolation and in Context by College Dyslexic Students. Brain and Language, 40, 471-490.

Bruck, M. (1993). Component spelling skills of college students with childhood diagnoses of dyslexia. Learning Disabilities Quarterly, 16, 171-184.

Bruck, M. (1990). Word-Recognition Skills of Adults with Childhood Diagnoses of Dyslexia. Developmental Psychology, 26(3), 439-454.

Critchley, M., (1981). Dyslexia: an overview. In: Pavlidis G.Th., \& Miles, T.R., (eds). Dyslexia Research and its Application to Education. Chichester: J. Wiley \& Sons, 1-11.

Defior, A., Cary, L., \& Martos, F. (2002). Differences in reading acquisition development in two shallow orthographies: Portuguese and Spanish. Applied Psycholinguistics, 23, 135-148.

Felton, R. H., Naylor, C. E. \& Wood, F. B. (1990). Neuropsychological Profile of Adult Dyslexics. Brain and Language, 39, 485-497.

Geschwind, N. (1986) Dyslexia, cerebral dominance, autoimmunity, and sex hormones. In Pavlidis G.Th., Fisher, D.F. (eds). Dyslexia: Neuropsychology \& Treatment. Chichester: J. Wiley \& Sons.

Giannouli, V. \& Pavlidis, G. Th. (2014). What can spelling errors tell us about the causes and treatment of dyslexia? Support for Learning, 2, 244-260.

Hanley, R. J. (1997). Reading and spelling impairments in undergraduate students with developmental dyslexia. Journal of Research in Reading, 20(1), 22-30.

Hatcher, P. J., Snowling, M. J., \& Griffiths, Y. M. (2002). Cognitive assessment of dyslexic students in higher education. British Journal of Educational Psychology, 72, 119-133.

Laasonen, M., Service, E., Lispanen, J., \& Virsu, V. (2012). Adult developmental dyslexia in a shallow orthography: Are there subgroups? Reading and Writing, 25, 71-108.

Landerl, K., Wimmer, H., \& Frith, U. (1997). The impact of orthographic consistency on dyslexia: a German-English comparison. Cognition, 63(3), 315-334.

Lehtola, R. I., \& Lehto, J. E. (2000). Assessing dyslexia in Finnish high school students: a pilot study. European Journal of Special Needs Education, 15(3), 255-263.

Leinonen, S., Müller, K., Leppänen, P. H. T., Aro, M., Ahonen, T., \& Lyytinen, H. (2001). Heterogeneity in adult dyslexic readers: Relating processing skills to the speed and accuracy of oral text reading. Reading and Writing: An Interdisciplinary Journal, 14, 265-296.

Lyon, R., Shaywitz, S. E., \& Shaywitz, B. A. (2003). Defining Dyslexia, Comorbidity, Teachers' Knowledge of Language and Reading: A Definition of Dyslexia. Annals of Dyslexia, 53, 1-14.

Meyler, A., \& Breznitz, Z. (2003). Processing of phonological, orthographic and cross-modal word representations among dyslexic and normal readers. Reading and Writing: An Interdisciplinary Journal, 16, 785-803.

Miller-Shaul, S. (2005). The Characteristics of Young and Adult Dyslexics Readers on Reading and Reading Related Cognitive Tasks as Compared to Normal Readers. Dyslexia, 11, 132-151. 
Miller, S. D., \& Smith, D. E. (1989). Relations among oral reading, silent reading and listening comprehension of students at differing competency levels. Literacy Research and Instruction, 29(2), 73-84.

Mortimore, T., \& Crozier, W. R. (2006). Dyslexia and difficulties with study skills in higher education. Studies in Higher Education, 31(2), 235-251.

Pavlidis, G. Th. (1981). Do eye movements hold the key to dyslexia? Neuropsychologia, 19, 57-64.

Pavlidis, G. Th. \& Miles, T.R., (eds.). (1981). Dyslexia Research and its Applications to Education. Chichester, J. Wiley \& Sons.

Pavlidis, G. Th. (1985). Eye movements in Dyslexia: Their diagnostic significance. Journal of Learning Disabilities, 18, 42-50.

Pavlidis, G. Th. (1990). Conceptualization, symptomatology and diagnostic criteria for dyslexia. In G. Th. Pavlidis (ed.), Perspectives on Dyslexia vol. 2, pp. 3-16. Chichester: John Wiley \& Sons.

Pavlidis, G. Th., (ed.). (1990). Perspectives on Dyslexia: Vol I, Neurology, Neuropsychology and Genetics. J. Wiley \& Sons.

Pavlidis, G. Th., (ed.). (1990). Perspectives on Dyslexia: Vol II, Cognition, Language and Treatment. J. Wiley \& Sons.

Pavlidis, G. Th. (2017). The biological significance of ophthalmokinesis: prognostic, diagnostic and therapeutic applications. Invited keynote speaker, $31^{\text {st }}$ Panhellenic Conference (with International participation) of Pediatric Surgeons, University of Macedonia, Thessaloniki, Greece, October 6-8.

Pavlidis, G. Th. (2018). Objective, biological prognosis, diagnosis of dyslexia \& ADHD and effective treatment internationally: Pavlidis Test \& Method. Invited Speaker, 4th International Dyslexia Conference of the Turkish Dyslexia Foundation, Osmangazi University, Eskisehir, Turkey, December 15.

Pavlidis, G. Th. (2019). Dyslexia: Psycho-social consequences. Invited Speaker, 1st International Congress on Psycho-Pedagogical Problem-Solving Strategies, Thessaloniki Concert Hall, Convention and Cultural Center Thessaloniki Greece, 12-13 April

Pavlidis, G. Th. \& Fisher, D., (eds.). (1986). Dyslexia: Its Neuropsychology and Treatment. Chichester, J. Wiley \& Sons.

Pavlidis, G. Th., \& Giannouli, V. (2003). Spelling errors accurately differentiate USAEnglish speakers from Greek dyslexics: Implications for causality and treatment. In R. M. Joshi, C. K. Leong, \& L. J. Kaczmarek (Eds.), Literacy Acquisition: The Role of Phonology, Morphology and Orthography. Washington: IOS Press

Pavlidis, G. Th., \& Giannouli, V. (2014). Linking ADHD - Dyslexia and Specific Learning Difficulties. In Garner, P., Kauffman, J.M. \& Elliott, J. (Eds.) Handbook of Emotions \& Behavioural Difficulties, London, SAGE.

Pavlidis, G. Th., \& Goula, M. (2004). Quantitative and Qualitative Differences in the Spelling Errors of Dyslexics and of Children with Mild Mental. Poster presented at the 5th World Congress on Dyslexia, Thessaloniki, Greece, 23-27 August.

Pavlidis, G. Th., \& Samaras, P. (2005). Ophthalmokinesis (Pavlidis test) objectively prognoses-diagnoses preschoolers at high-risk for ADHD. Paper presented at the $27^{\text {th }}$ Colloquium of the International School Psychology Association, Athens, July 13-17. 
Ransby, M. J., \& Swanson H. L. (2003). Reading Comprehension Skills of Young Adults with Childhood Diagnoses of Dyslexia. Journal of Learning Disabilities, 36, 538-555.

Rapti, S., Pavlidis, G. Th., \& Garner, P. (2018). The very slow reading speed highly differentiates dyslexic from non-dyslexic University students. In the $1^{\text {st }}$ interdisciplinary conference of Special Education and Treatments: The contribution of modern approaches from children to adults. Athens, Greece.

Rapti, S., Pavlidis, G. Th., \& Garner, P. (2013). Quantitative \& qualitative differences in reading between dyslexic and non-dyslexic students. Paper presented at the 2 nd Conference on special education, Athens, Greece, April 11-14.

Singleton, C. H., \& Aisbitt, J. (2001). A Follow-Up of the National Working Party Survey of Dyslexia Provision in UK Universities. Paper presented at the $5^{\text {th }}$ British Dyslexia Association International Conference, University of York.

Shaywitz, S. E. (1998). Dyslexia. The New England Journal of Medicine, 338(5), 307-312. Shaywitz, S. E., \& Shaywitz, B. A. (2005). Dyslexia (Specific Reading Disability). Biological Psychiatry, 57(11), 1301-1309.

Stampoltzis, A., \& Polychronopoulou, S. (2008). Dyslexia in Greek higher education: a study of incidence, policy and provision. Journal of Research in Special Educational Needs, 8(1), 37-46.

Taylor, N. E., \& Connor, U. (1982). Silent vs. Oral Reading: The Rational Instructional Use of Both Processes. The Reading Teacher, 35(4), 440-443.

Wimmer, H. (1993). Characteristics of Developmental Dyslexia in a Regular Writing System. Applied Psycholinguistics, 14, p.1-33.

Wimmer, H., \& Goswami, U. (1994). The influence of orthographic consistency on reading development - word recognition in English and German children. Cognition, 51, 91- 103.

Ziegler, J. C., Perry, C., Ma-Wyatt, A., Ladner, D., \& Schulte-Körne, G. (2003). Developmental dyslexia in different languages: Language-specific or universal? Journal of Experimental Child Psychology, 86, 169-193.

\section{ОСОБЛИВОСТІ ЧИТАННЯ СТУДЕНТІВ 3 ДИСЛЕКСІЄЮ У ВИЩИХ НАВЧАЛЬНИХ ЗАКЛАДАХ ГРЕЦЇ̈}

Рапті Софія, доктор наук зі спеціальної педагогіки, науковий співробітник «Центру дислексії - метод Павліді», вул. 31Августо, 4, 41221 Лариса, Греція, sofrapti@gmail.com

Павліді Джордж, кандидат психологічних наук, науковий директор «Центру корекції дислексії - метод Павліді», вул. 31 Августо, 4, 41221 Лариса, Греція, gpavlidiss@yahoo.com

До недавнього часу переважну більшість досліджень щодо дислексії зосереджували на англомовному населенні та дітях, які, через непослідовність анг- 
лійської мови схильні читати значно повільніше та неточно. Це призвело до помилкового припущення, що головною ознакою дислексії $\epsilon$ неточне читання. Однак, результати досліджень фонологічно-послідовних мов (таких як грецька, італійська, німецька, фінська) показали, що швидкість читання $\epsilon$ основним недоліком дітей та дорослих, які страждають дислексією. У статті досліджено відмінності в процесі читання (щвидкість читання, точність та розуміння) між студентами (26) з дислексією та їх ровесників (28), які не страждають на дислексію. Всі учасники відповідали віку, статі та соціально-освітньому рівню.

Зроблено висновок, що студенти з дислексією значно повільніше читали та робили більше помилок, однак, була однакова швидкість читання вголос та мовчки на відмінну від іх ровесників, які набагато швидще читали в режимі мовчки. Зазначено, що саме швидкість є основною відмінною рисою в процесі читання студентів із захворюванням, адже рівень точності складає 98,1\%.

Ключові слова: дислексія, дорослі, студенти, читання, швидкість читання, точність та розуміння прочитаного.

Received: 19.11.2019

Accepted: 26.12.2019

Passed for printing ?????.2019

Format 70x100/16. Minion Pro.

Offset paper/ Conventional printed sheets ????

Number of copies ???. Order ?????. 